Valóságos könyvtár - könyvtári valóság. Könyvtár- és információtudományi tanulmányok 2018. Szerk. Kiszl Péter, Csík Tibor.

Budapest, ELTE BTK Könyvtár- és Információtudományi Intézet. 2018. 181-189.

\title{
SELF-PUBLISHING
}

\section{A KÖNYV-ÖNMENEDZSELÉS IRODALMI ÉS KIADÓI MODELLJÉRŐL}

\author{
KEREKES PÁL \\ ELTE BTK KITI, címzetes egyetemi docens
}

\section{TARTALMI ÖSSZEFOGLALÓ}

A self-publishing egy új kiadói modell. Nevezik független kiadásnak is. Lényege, hogy a szerző maga menedzseli a könyv megjelenését, majd a későbbiekben a forgalmazását. Ez lehet ingyenes, de lehet beárazott termék is. Amennyiben a kiadvány árusításra kerül, a szerző számára előnyős, hogy jóval nagyobb jutalékot kap a könyve után, mint a hagyományos kiadói rendszerben. A könyv egy self-publishingre szakosodott portálra tölthető fel. Magyarországon a Publio Kiadó a selfpublishing portál.

Jelen tanulmánynak nem célja a self-publishing (saját kiadás, szerzői kiadás) kategorizáló értékelése, különösen nem ajánló jellegű fejtegetése. Az írás nem elemzi a selfpublishing üzleti vonatkozásait és nem foglal állást a független publikálást kísérő irodalomszemléleti, illetve kultúrpolitikai problémafelvetésekről sem. A következő fejezetek szándéka az, hogy megismertesse a self-publishing jelenséget, amely döntôen kötődik az e-könyv médiumhoz, valamint a digitális könyvkiadás - nyomtatott környezetből származó - új szolgáltatásaihoz.

A szinte követhetetlen gyorsaságban és mennyiségben alakuló e-book portálok - feltételezve a kulturális motivációt - azt látszanak bizonyítani: az üzleti és könyvfilozófiai merevség, a kiadói print strukturáltság - több elemében - elveszti létalapját a számítógépes literatúra-környezetben. Tapasztalathoz és tudásalkotási potenciálhoz gyorsabban lehet jutni, mint valaha. Az elektronikus felületek korlátlanok, befogadják és szolgáltatják a mûvészi alkotások minden formáját, köztük a legegyszerűbben prezentálható szöveges munkákat. Az ellenőrizetlenül ömlesztett fájl massza kritikusai azonban - kármegelőzés vagy utólagos kármentés forrongásával - joggal állapítják meg: a megosztás médiakultúrájában nem pontosan meghatározottak a szerepek és felelősségek. Hamarjában bárki lehet közlő - blog, szöveg- és fotómegosztó oldalak, mozgósító posztok -, és az is igaz: bárki lehet olvasó, ha nem is volt eddig a betűk nyújtotta tény- és érzelmi információkhoz szokva. Az univerzum „dokuverzumra”1 manifesztálódik, a szövegek pluralisztikus szövevényében stílust és kapcsolódási pontokat találhatnak a közlés hagyományos mintáit nem gyakorlati szinten ismerő témafelfedezők, élményiniciátorok is. 


\section{KEREKES PÁL}

A self-publishing egy lehetőség, amelynek tanulmányozására - mérete és gyors terjedése miatt - világszerte nagy figyelmet fordítanak irodalmi, kiadói, üzleti szinten, valamint tudományos publikációs szempontból. Összefoglalásom megkísérli bemutatni a sokszor ellentmondásosan rokonított publikációs technikák - magánkiadás, selfpublishing - különbözőségét és közös vonásait is.

\section{Self-publishing, független publikálás}

Mit hordoz az a kifejezés: szerzői kiadás? Van-e már kialakult magyar fogalomrendszer a self-publishing aktivitás ismérveire? Hogyan értelmezhető: független és szabad publikálás? A Gutenberg-korszak helyett már a „Google-tenberg” intelligencia idejét éljük? Mindezek a felvetések mögött ott húzódik a megkerülhetetlen alapkérdés: felválthatja-e az önmenedzselésű elektronikus könyv a hagyományos nyomtatott kiadványok bibliopola rendszerét? A válasz - ellentétben sok függőben maradó informatikai kérdésfelvetéssel - ez esetben egyértelmű nem. A számítástechnika térnyerése következtében kibontakozó textuális átalakulás nem gyengíti, hanem megerősíti azt az elméleti állítást és napi tapasztalatot, hogy a digitális könyv és más elektronikus könyv-származékok, beleértve a szöveg dominanciájú tartalom-hibrideket is, csak az évezredes könyvkultúra összefüggésrendszerében értelmezhetők. Ez a megközelítés azonban nem zárja ki, hogy érzékeljük, és vizsgálat tárgyává tegyük: az elektronikus szövegalkotásokban kétségtelenül kialakultak olyan gyökeresen új literatúra elemek, amelyek elemzése szükséges és elmaradhatatlan. Még akkor is igaz ez, ha nyilvánvaló: az értelmes eredménnyel kecsegtető analízis csak több bölcsészeti tudományterület együttmúködésében valósítható meg, tekintve az e-könyv térség elágazó problémaköreit. Egyáltalán, informatikai vagy könyvészeti projekt az elektronikus betűtartományok problémáinak vizsgálata? Karakterek, kijelzőfelbontások, chip-teljesítmények laboratóriumi vizsgálata visz közelebb az e-könyv kultúra megértéséhez, vagy a szövegterek papírra feszített változatainak, esetleg digitális verzióinak boncolgatása? Biztató, hogy alapozó vizsgálatok tárgya már ma is az az ismeretlen vagy annak hitt hermeneutikai zóna, amelyben a mú és az olvasó kapcsolatát az elektronikus text befogadása körüli problémák jellemezik.

A kibontakozó e-book kultúra bővíti, gazdagítja az irodalmi megjelenés lehetőségeit. Az írás köztevékenységgé fejlődött. Akinek van közölnivalója és képes is azt megformálni, módot teremthet a megjelenésre. Rendelkezésre állnak a blogok, fórumok, weboldalak. Szabad a pálya az intézményesített tereken is. A professzionális kereskedelmi és terjesztői hálózatokon lehetôséget nyújt a közzétételre a szerzői kiadás, a self-publishing, a független publikálás. Nincs gátja formailag, technikailag a médiatizált gondolatközlésnek. És eszmeileg, etikailag? Kommunikációs dilemmaként kell kezelni az írószobák szövegmanufaktúráin túllépő tömeges text-termelést, vagy irodalomelméleti vonatkozású vizsgálatok is szükségessé válhatnak? A könyvszerzőség kevesek monopóliumából sokak megnyilatkozási formája lett. Ez az informatikai fejlemény nyelvi, esztétikai, irodalmi keretrendszerek változását is jelentheti. 
SELF-PUBLISHING. A KÖNYV-ÖNMENEDZSELÉS IRODALMI ÉS KIADÓI MODELLJÉRŐL

\section{Az irodalom laikus müvelöi}

A self-publishing az elektronikus könyvkultúra - noha bőven vannak előzményei a print korszakból - új jelensége. Ebben az informatikai konstrukcióban a szerző maga tölti fel művét egy könyváruházba, és egyedül dönt a mű további sorsáról. Szándékainak és ízlésének megfelelően határozza meg az árat, a kiadás lokalizációját (Magyarországon vagy más globális portálokon is árulják-e), a mű formai jegyeinek főbb elemeit. Egész konkrétan kimondható, hogy a publikálásra szánt múvet közvetlenül az író juttathatja el az érdeklődőknek. Ez is a neve az új könyvmozgalomnak: független kiadás, vagy más oldalról nézve: független szerző. A független ez esetben természetesen nem a tartalomra vonatkozik, hanem a megjelentetés szisztémájára. A szöveg elektronikus változatából könnyen készíthető nyilvánosság számára is elérhetővé applikált írásmű. Hamar felismerték ezt az igényt és lehetőséget a globális könyv-vállalkozások és megteremtették a self-publishing közlési és múelérési modellt.

Az elektronikusan prezentált irodalom számos új alkotórészének a self-publishinget érintő fő hipotézise nem más, mint az a már többször megállapított e-szöveg jellemző: az elektronikus közegben - részben vagy az egész felé haladva - feloldódnak az irodalmi funkciók közötti hagyományos határok. Az olvasó gyakran más szerepkörben, egyenesen a szerzőében találja magát. Az írónak alárendelt logikájú, analóg tartalom-feldolgozás helyébe a digitális kiterjedésü, hipertextes vezetettség lép. Az elágazások nem uralhatók, az olvasó maga rajzolja a megértés-térképeket. Az eltévedés esélye jelen van (csakúgy - ez aligha tagadható, de történelmileg elfogadottá szelídült módon -, mint a más csapdákat rejtô, hierarchikus felépítésű múvekben).

Mark Coker, a legnagyobb self-publishing portál életre hívója és máig üzemeltetője, így fogalmazza meg a self-publishing auktor motivációját: „A könyvsiker nem mérhető kizárólag pénzzel. Amint az elsó olvasó fellapozza a könyved, már kivetted a részed a világ átalakitásából. És ez csak a kęqdet!’’2 (Kerekes Pál fordítása) Az iniciátor Mark Coker iránymutatásából is kitetszik, hogy a self-publishing elsősorban mint örömírás faktor üt rést a hagyományos kiadói rendszereken. A tartalmi kvalitás, a stílusbiztonság mellett más ismérvek is, például családi felkérés, a szerző életében bekövetkezett változás inspirálhatnak és nyilvánosan elérhetővé tehetnek - egyéni vagy társadalmi költekezés nélkül - egy írásmûvet. Talán ez lehet a self-publishingban rejlő egyik legnagyobb bölcsészeti innováció.

Az író, a szerző, az alkotó megszokott és elfogadott funkcionalitása mellett színre lépnek a self-publishing kultúrkörben a nem professzionális közremúködők, olyan irodalombarátok, jó értelemben vett amatőrök, laikusok, akik nem minden esetben törekszenek az eredetiségre, vagy a rendkívülire. Megelégszenek a leírással, élményközléssel, egy várhatóan szűk érdeklődésre számot tartó, de adott körben mégis fontos témafeldolgozással. 
KEREKES PÁL

\section{A self-publishing és a szerzôii kiadás különbözoósége}

A self-publishing előzményének tekinthető szerzői kiadás nem új jelenség a könyv világában. Ez a médiátori konstrukció csak az utóbbi évtizedekben kapott vállveregető, lekicsinylő árnyalatot. Nagy költőink, íróink kétszáz évvel ezelőtt - pénzügyi kényszerből, minden mellékzönge nélkül - előfizetőket kerestek könyvterveikhez. Magyarországon és szerte Európában az volt a gyakorlat, hogy az író maga menedzselte a nevével jelzett kiadványt. Annak idején a legkiválóbbaknak is kényszerű előfizetési felhívásokat kellett fogalmazniuk műveik kiadása érdekében. Szponzoráció felkutatása céljából tengernyit leveleztek, hiszen a kulturális támogatás - mint a könyvkiadás anyagi bázisfeltétele - kieszközlése többnyire a szerzőre maradt. „... föhajtva könyörögvén Excellenciádnak, hogy ą̧t hatalmas szárnyai alá venni s a világra lejendö kijöhetésére felsegélleni méltóztassa” - írja Széchényi Ferencnek Csokonai, egy könyvtervéhez támogatást kérve. ${ }^{3}$ De a XX. században sem volt ritka a szerzői kiadói kezdeményezés. Tanulságos leveleket lehet ebben a témában olvasni Tevan Andor hátramaradt irattárában. ${ }^{4}$ Kiderül, hogy ma méltán klasszikusoknak tekintett írók milyen nehezen szereztek támogatót - ha szereztek egyáltalán - kezdő múveik kiadására. Látható, hogy Déry Tibor, Juhász Gyula, Kassák Lajos és még sok más kiváló szerző nem talált más utat, mint a szerzői utánajárást és anyagi kockázatot. Folyamatosan kértek nyomdai ajánlatot magánkiadású könyvterveikhez.

A self-publishing és a magánkiadás (szerzői kiadás, vanity press) közötti különbségek a következőkben foglalhatók össze:

- magánkiadás esetén a könyv átmegy minden jellemző kiadói munkaműveleten (lektorálás, korrektúra, könyvtervezés, címlap, tipografizálás), ám a szerző költségére és anyagi kockázatára;

- a self-publishing formációban a szerző maga (vagy előzetesen megbíz egy szakembert részfeladatokra, pl. címlap készítése) végez minden publikációs műveletet, a szöveggondozást is beleértve, és maga tölti fel a művét egy self-publishingra szakosodott portálra (Smashwords, Creativ Space, Lulu, Bookbaby, magyar: Publio), vagy globális könyvkiadók self-publishing felületére (Amazon, Kobo);

- magánkiadás esetén a mű a könyvkereskedői, terjesztői rendszeren át kerül értékesítésre, a marketinget a kiadó és a terjesztő-kereskedő végzi;

- self-publishing konstrukcióban a self-publishing portál forgalmazza (bevonva minél több e-könyv áruházat hazai és nemzetközi szinten) a művet, de nem nyújt marketing támogatást. Ezt a szerző maga végzi, a saját kreativitása alapján, pénzügyi lehetőségei tükrében;

- self-publishing esetén alapkövetelmény a befogadó portál részéről a nemzetköziség: tehát a szerző művét a hazai e-könyv áruházakon kívül az iTunes, a Google Play, Kobo, és más globális portálokon is terjeszti eredeti nyelven (ez nem mindig magyar). 
SELF-PUBLISHING. A KÖNYV-ÖNMENEDZSELÉS IRODALMI ÉS KIADÓI MODELLJÉRŐL

\section{Könyvkeletkętetési modell}

Hogyan múködik a self-publishing a gyakorlatban? A self-publishing - ugyan a szerzői kiadás előzményre tekint vissza - döntően más konstrukció. Az alapvető különbség, hogy a szerzô válik teljes egészében a mú szellemi és formai kivitelének felelősévé. Kiadói, azaz könyvszakmai kontroll nélkül jelenik meg a mű. A szerző azonban nemcsak a megírásért felel, hanem a könyv utóéletéért is. Az ő késztetése és aktivitása kell ahhoz, hogy a múve ismertté váljon. Ehhez általában a közösségi internetoldalakat veszik igénybe. A blogírás alapkövetelmény. Mivel a szerző az egész folyamatot kézben tartja, a megírástól az eladásig, a self-publishing kifejezés helyett élőbb és valóságosabb lenne az önmenedzselésű könyvkiadás fogalma.

Az egyszerűség kedvéért azonban még maradva a self-publishing meghatározásnál, a legfontosabb kérdés nyilvánvalóan az, hogy a gyakorlatban miképp is működik ez a konstrukció? Lényegi elemei a következők:

- Létrejön és múködik egy self-publishing portál, amely felületet biztosít a szerzők számára műveik feltöltésére. Ez a portál gondoskodik a művek konverziójáról. (Általában Word-ben kell feltölteni, ezt alakítják át ePub-ra, Mobi-ra, és más formátumokra.) A portál minden alapszolgáltatása a szerző részére ingyenes.

- A szerző rendelkezik olyan informatikai jártassággal, hogy képes feltölteni a szöveget és a címlapot, valamint az opcionális tartozékokat: tartalmi ismertető, múfaji meghatározás, blog és webcímek megadása. A legalapvetőbb számítástechnikai használói ismeretek elegendőek, különben nem is működne a konstrukció.

- A self-publishing portál biztosítja a szerzőnek a könyveladások forgalmi adatainak napi szintű követését úgynevezett szerzői oldal segítségével.

- A self-publishing portál végzi az eladást, a back-office feladatokat.

- A szerző a könyvkiadásban szokásos 8-15\%-os szerzői jutalék helyett jóval nagyobb mértékű, legalább 60-70\%-os részesedést kap a bevételből.

Az összes nagy globális könyvforgalmazó működtet self-publishing szekciót. A legismertebbek: Amazon: Kindle Direct Publishing (https://kdp.amazon.com), Barnes \& Noble: Pub it!, újabban: Nook Press (https://www.nookpress.com), Kobo: Writing Life (http://www.kobo.com/writinglife).

A self-publishing elterjedését, és mint elfogadott könyvnyilvánossági műfajnak elfogadottságát jelzi, hogy a legnagyobb tekintélyű ingyenes e-book adatbázis, a Gutenberg Project is külön self-publishing szekciót hozott létre. ${ }^{5}$

Magyarországon is jelen van a self-publishing a nagy szabad (free) könyvállományokban. Az Országos Széchényi Könyvtár (OSZK) keretében múködő Magyar Elektronikus Könyvtár ${ }^{6}(\mathrm{MEK})$ is befogad kortárs szerzőktől alkotásokat. Nem változtat a szövegen, nem végez a beadott írásokon hagyományos kiadói tevékenységet, tehát a szöveget változatlan formában adja közre. A megkeresés is szerzői oldalról érkezik, ennyiben is kapcsolódik a self-publishing modellhez. A self-publishing erejét mutatja, 


\section{KEREKES PÁL}

hogy jelenleg is a naplózott letöltések alapján az első ötben (2015. február) két élő szerző műve áll. Mindkét könyv hónapok óta az élen van, voltak hosszú időszakok, mikor az első két helyet töltötték be. ${ }^{7}$ A MEK sikerlista oldalán folyamatosan követhető a legnépszerübb könyvek tabellája. Sok meglepetés érheti az elemzőt, ha folyamatosan nyomon követi: a napi három-négyezer egyedi látogató - ilyen értelemben az ország legnagyobb könyvtára - milyen évszakban, milyen napszakban, milyen címeket böngész, majd tölt le (napi több százezres oldal mennyiségben). Ha még ezt összeveti globális közcélú portálok (Gutenberg project, Europeana) látogatottsági adataival, karakteres könyv-viszony attitűdöket értelmezhet. Több megyei könyvtár is külön virtuális polcot nyújt helyi szerzőknek, legyen az szépirodalom vagy szakmunka. Itt fel is tüntetik: „A szerzőtől kapott példány alapján”. A szolnoki Verseghy Ferenc Könyvtár Verseghy Ferenc Elektronikus Könyvtára egy tanulmányozható példa. ${ }^{8}$

\section{Smashwords, a self-publishing csúcs portálja}

A legnagyobb önálló self-publishing portál, tulajdonképp a self-publishing első sikeres oldala a Smashwords. Mark Coker, a cég alapítója és múködtetője így számol be a cég alakulásáról a 2012. év végén”: „A Smashwords-öt 1998-ban alapitottam azért, hogy változtassak a könyvek kiadásán, terjesztésén, forgalmazásán. Láttam, hogy a tradicionális könyvkiadás a szakadék szélére jutott. A kiadók - érdektelenségböl, hajlandóság hiján - képtelenné váltak esélyt adni az iróknak a megjelenésre. Mára a Smashwords a független szerzók és kiadók legnagyobb könyvforgalmazója lett az egész világon. A Smashword alapgondolata egyszerü: létrehozni egy olyan szabad self-publishing platformot, ahol a szerző́k nem kockáztatnak a megjelenéssel. Minden irónak meg akartam adni a szabadságot a nyilvánosság eléréséhez és minden olvasónak, hogy szabadon válasžthasson a müvek között.” (Kerekes Pál fordítása)

A talán kissé túlzó megfogalmazás sokkal komolyabbá válik, ha megismerkedünk a számokkal. ${ }^{10}$

- 2017-ben, egy év alatt 34900 új múvet töltöttek fel a világ minden tájáról. (A feltöltésnek nincs nyelvi korlátja, tehát magyarul is lehet publikálni.)

- 2017 decemberében a feltöltött művek száma: 472 100. A számláló jelenlegi állása szerint (2017. január 30.) 16870977335 szóból áll a könyvállomány.

- Akadt olyan év (2012), amikor a művek számának gyarapodása elérte a százezret.

- A szerzők száma összesen: 133 175, a 2017. évi növekedés: nagyságrendileg 8000 szerző.

- Érdekességként megállapítható, hogy arányaiban a szerzők száma nem növekszik olyan gyorsan, mint a múvek száma. Ebből az következik, hogy egyes szerzők egyre több könyvet publikálnak.

Mark Coker megadja rövid tőmondatokban a self-publishing sikerének magyarázatát is:

1. A független szerzők egyre profibbak lesznek, tanulnak. 
SELF-PUBLISHING. A KÖNYV-ÖNMENEDZSELÉS IRODALMI ÉS KIADÓI MODELLJÉRŐL

2. A szerzők írnak, mert látják, hogy érdemes, lesz megjelenés.

3. A kereskedők szívesen fogadják a self-publishing könyveket.

4. A self-publishing olcsó mindkét szereplőnek: a szerzőnek és az olvasónak.

5. Az olvasás a képernyőre vonul, kellenek az új művek.

6. A self-publishing globális. Nincsenek határok.

7. A self-publishingról lekerült a minőség-gyengeség stigmája.

Természetesen vannak ellenzői is a self-publishing kiadásnak és terjesztésnek. A legfőbb kifogások a következők:

- Nem ellenőrzött nyelvi minőségű könyvek tömegében való megjelentetése káros a kultúrára, mûvelődésre.

- Írók, szerzők felbiztatása nem megalapozott karrier-álmokat ébreszthet.

- Gyakoriak a másolások, hamisítások, szöveg-összevágások, dúl az epigonizmus.

- Írói szenvedélybetegség kialakulhat, fellép a publikációs kényszer.

A Smashwords mellett több más self-publishing portál működik, a legismertebbek: Lulu (www.lulu.com), Bookbaby (www.bookbaby.com).

\section{Egyéb kiadók, magyar portál}

Magyarországon az első és mindmáig egyetlen self-publishing portál a Publio. ${ }^{11}$ Könyvei a saját könyváruházán kívül elérhetők a legnagyobb magyar könyves plázákon. A 2011-ben indult kiadói portálon és könyvplázán ${ }^{12}$ a kézirat leadásának napjáig (2018. január 30), 1871 könyvet töltöttek fel. A regisztrált szerzők száma 2730. Ez az adat tényszerűségében és tendenciájában különbözik a globális portál, a Smashwords kimutatásaitól. Itthon egy szerzőre még egy könyv sem jut, míg a Smashwordsnél egy szerzőre három átlagosan. Ezek a számok sokat mondanak és értelmezhetők, de nem feladata az elemzése ennek a tanulmánynak. A Facebook oldal lájkolóinak száma nagyban meghaladja a tízezret.

A self-publishing néhány év alatt mozgalommá, írói magatartásformává alakult, saját sajtóval, könyvtárnyi szakirodalommal, jelentős gazdasági befolyással. A sorra megjelenő, majd megbukó e-book üzleti konstrukciók közül azon kevés kivételek közé tartozik, amely fenntartható (biznisz értelemben) és bővülő modellt produkált. A selfpublishing fogalom jól hangzó márkává vált. A független publikálás ma már brandnek számít. Néhány év alatt a self-publishing elfogadottá vált, a könyvtermés jelentős hányadát ma már a független szerzői kiadású művek adják az elektronikus könyváruházakban. A professzionális szerzők is folyamatosan térnek át erre a konstrukcióra, hiszen így - kihagyva a közvetítő szervezeteket - a megírás tiszteletdíja a hagyományos értékesítési jutalékból a 10-15\%-ról egyöntetűen 70\%-ra ugrik. Az USA-ban, a legérettebb e-book piacon, 2011-ben 247210 ISBN számot adtak ki self-publishing írásmúre, 2016-ig ez a szám már 786935 darabra emelkedett. Csak egy év alatt, tehát 2015. évről 2016. évre az emelkedés elérte a $8,3 \%$-ot. ${ }^{13}$ 
KEREKES PÁL

\section{Self-editing, könyufelújitás, kéziratfeldolgozás e-könyvre}

A self-publishing egyik leágazása az önmenedzselésű könyvfelújítás. Az alkotó ez esetben nem arra vállalkozik, hogy originális művet hozzon létre, hanem egy általa fontosnak tartott, de a könyvforgalomban már nem kapható kötetet, vagy a könyvforgalomba sosem került kéziratot e-könyvre szerkeszt. Jó példa erre a lokalitás témaköre. Hány szamárfüles, szétírt papírfüzet veszett el, mert nem volt kiadója az ilyen írásoknak. Nem is lehetett, hiszen nem éri meg kinyomtatni olyan anyagot, amelyre csak egy szúk környezet lehet vevő. Vagy hány emlékezés, családi krónika pusztult el költözéskor, tatarozáskor, bontáskor! Ezt se volt érdemes bolygatni; minek azért a néhány emberért, aki esetleg kezébe venné? Most más a helyzet. Az e-book világában a kiskönyv is életre kelhet, hiszen az eleve vélhetően korlátok között jelen lévő érdeklődés miatt is érdemes nyilvánosságot keresni. Hiszen kinek lehet fontos egy városnegyed, egy utca históriája? Azoknak, akik ott élnek, és számukra ez meglapozható, akár kiolvasható tartalom. Digitális útra kelhetnek a naplók, eseménytárak, visszaemlékezések. Előkerülhetnek olyan írások a könyvespolcról - persze lejárt jogúak természetesen -, amelyeket fontosnak tartanak gazdái esetleg ismét megjelentetni, akár nem teljességében, csak egy-egy kevéssé avuló részleteiben. Lehet összeállításokat szerkeszteni, tartalmi vagy témakör alapon. Minderre már van példa, elindult a könyvszeretet ilyen típusú kiélése is. A korrekt alkotói megjelölés természetesen velejárója kell legyen a könyvfelújításnak. A szerzố és örökösei anyagi és kiadási igénye ugyan lejár hetven évvel a halála után, de a mú nevéhez kötődésének és szellemiségének megváltozhatatlanságához kapcsolódó joga örök.

A self-publishing - nem legfőképp mint szerzői magatartás, hanem mint szövegújjáélesztő aktivitás - megjelenik a nem kereskedelmi könyves intézmények tereiben is. Egy kanadai város, Windsor közkönyvtárába kihelyeztek egy könyvautomatát, azaz egyszerű fájlból (tehát nem speciális szoftverrel kezelt szövegből, és különösen nem tördelő programmal előkészített nyomdai nyersanyagból) teljes értékű papírkönyvet készítő berendezést. Neve: Espresso Book Machine. ${ }^{14}$ A könyvtárosok publikálták a géppel kapcsolatos megfigyeléseiket és tapasztalataikat. ${ }^{15}$ Megállapították, hogy hoztak ugyan saját múveket is az olvasók nyomtatásra, de ugyanilyen, illetve nagyobb számban fordult elő, hogy feltalált szövegeket (rokonok, ismerősök műveit, már nem vásárolható könyvek digitalizált verzióit) rendeztek könyvbe. A kutatásban részt vevő szakemberek rögzítették: az új technikai eszköz nemcsak a könyvtárlátogatók számítógép idegenkedésének oldásában játszott szerepet, hanem létrejött egy váratlan fejlemény is: könyves közösségek alakultak a book-gépezet képességeinek kihasználására. Alkotó viszonyulásba kerültek a könyvtár használói a könyvvel. Olvasói művelődési kapcsolatrendszerük kibővült, kisközösségi kiadói funkciók kezdeményezésére jelentkeztek be. 


\section{Jegyzetek}

1. Ted Nelson kifejezése. A fogalomról bővebben: NELSON, Ted: Hipervilág - a szellem új otthona. Forrás: http://www.artpool.hu/hypermedia/nelson.html [2018. január 20.]

2. COKER, Marc: Ebook publishing gets more difficult from here - Here's how to succeed. 2014. november 19. Forrás: http://blog.smashwords.com/2014/11/ebook-publishing-gets-moredifficult.html [2018. január 20.]

3. A forrás adatai hiányoznak 1798. január 23. Komárom.

4. VOIT Krisztina: Tevan Andor levelesládájából. Budapest, Gondolat Kiadó, 1988. 449 p.

5. Project Gutenberg Self-Publishing Press. Forrás: self.gutenberg.org

6. A Magyar Elektronikus Könyvtár nyitó oldala: www.mek.oszk.hu [2018. január 20.]

7. COlTON, Steve P.: Danceland. Forrás: http://www.mek.oszk.hu/07300/07325/index.phtml; PÁVEL István: Szex, szerelem és egyéb csacskaságok. Forrás: http://www.mek.oszk. hu/08500/08518/index.phtml [2018. január 20.]

8. Verseghy Ferenc Elektronikus Könyvtár: http://portal.vfmk.hu/vfek.

9. Smashwords Year in Review 2012 - The power in publishing is shifting to authors. Forrás: http://blog.smashwords.com/2012/12/smashwords-year-in-review-2012-power-in.html [2018. január 20.]

10. Smashwords 2017 Year in Review und 2018 Preview. Smashwords Blog, 2017. dec. 31. Forrás: http://blog.smashwords.com/2017/12/smashwords-2017-year-in-review-and-2018.html [2018. január 20.]

11. A Publio Kiadó kiadói oldala: www.publio.hu [2018. január 20.]

12. A Publio Kiadó könyváruház oldala: www.konyvaruhaz.info ; www.publioboox.com [2018. január 20.]

13. Self-publishing in the United States 2011-2016. Print and EBook. Forrás: http://media. bowker.com/documents/bowker-selfpublishing-report2016.pdf [2018. január 20.]

14. Az eszközt bemutató magyar nyelvű ajánló anyag leírása szerint: Az Espresso Book Machine $^{\mathrm{TM}}$ a Xerox ${ }^{\mathrm{TM}}$ teljes mértékben integrált, nagy sebességú, kompakt megoldása a tökéletes kötésú, könyvtári minőségű papírfedeles könyvek automatikus nyomtatására, kötésére és vágására - rendelés alapján, az értékesítési ponton. Amíg megiszik egy csésze kávét, könyve el is készül.

15. PERrY, Sue: How a self-publishing lab created a new literary community. = Library HI Tech News, 31. vol. 8. no. 2014. 12-14. p. https://doi.org/10.1108/lhtn-07-2014-0055 [2018. július 27.]

Kerekes Pál az ELTE BTK Könyvtár- és Információtudományi Intézetének címzetes egyetemi docense. Több szakkönyv szerzője. Kutatási területe az e-könyv, az e-tartalom. 